\section{Help business and survive}

THE British government's long-promised Green Paper (discussion document) on higher education, published earlier this week (Cmnd 9524, HMSO, £5.80), does nothing to suggest that the pressure on university and polytechnic budgets will be relieved. Indeed, the government says that planning for the impending fall in student numbers, expected on demographic grounds in the 1990s, "will need to begin shortly". The document says that these changes will require "not only rationalization within institutions but the amalgamation or closure of whole institutions"'.

The document says that there is a need for "means of assessing, on educational and economic grounds", where capacity should be reduced, promises that the chief advisory bodies (the University Grants Committee, UGC, and the National Advisory Body, NAB, which represents the polytechnics), will "have a key role" and adds that "the government will be fully engaged". The government notes the pleas of both bodies as well as of the Jarrett committee on university administration (see Nature 4 April, p.392) that institutions should be given longer notice of the public funds at their disposal, but says that its three-year rolling forecasts are the most it can provide, and that higher education institutions should be able to accommodate "change and some inevitable uncertainty".

To most academics, the green paper will be a disappointment, not for what it says or neglects to say but for its tone. The keynote is the statement in the introductory section that "the government believes it is vital for our higher education to contribute more effectively to the improvement of the performance of the economy". Referring to its own initiatives to improve the quality of science teaching in schools, the government says that there "would be no point in continuing to provide more places in science and technology in higher education" unless there are enough able students to fill them, urges that universities and polytechnics should plan for flexibility in the face of change and demands that "higher education establishments" should abandon "anti-business snobbery" and, instead, should foster entrepreneurship, should "go out and develop" links with industry and commerce and should form strong connections with local communities.

With qualifications, the green paper accepts the redefinition by $\mathrm{UGC}$ and NAB of the principle that suitably qualified students should have access to higher education (the "Robbins principle") by agreeing that "courses of higher education should be available to all those who can benefit from them and who wish to do so". The qualification is that "so long as taxpayers substantially finance higher education ... the benefit has to be sufficient to iustify the cost". The "test of

\section{Interferon}

ability to benefit" should be applied as stringently to those with formal qualifications as to those without.

Inevitably, the green paper rehearses the government's position on the future demand by students for places in higher education, but promises a more considered estimate of demand after a survey now being carried out among young people. Meanwhile, it says, the funds now promised should suffice to allow universities and polytechnics to meet the demands on them in the three years ahead. The document says that UGC and NAB have been asked to recommend how students should be distributed between the universities and the polytechnics, but asks that students should not be admitted to universities if they are more likely to benefit "in terms of personal development and future employment prospects" from a course at a polytechnic.

On research, the green paper rejects the argument of UGC that "research stimulates the teaching of able students" with the statement that "there is no evidence that all academic staff must engage in research"'. It applauds UGC's plan to distribute research support selectively, hopes that a start will be made in 1986-87 and notes that one consequence may be that "some departments or even whole universities will lose research funding (sic) from the UGC'". The green paper says that universities will still be free to seek the funds from private sources.

With more enthusiasm, the green paper argues the benefits that would accrue to academics and to "business" from a closer relationship between them, and urges academic institutions to take account of industrial consultancies when assessing candidates for promotion, to encourage academics to "engage in business activity", if necessary on part-time academic contracts, to strike "reasonable deals" with staff over the income earned from innovations and to operate industrial liaison services. (Cautiously, the green paper warns academic institutions of their potential insurance liabilities in these activities.) In the same spirit, the government says it has asked UGC that success in industrial collaboration should be given "due recognition".

The green paper also says the government is not convinced that two-year degree courses are feasible, but would like to see them tried, and that it is dismayed at the growth of the numbers of students now following four-year courses. The paper also says that the government is planning to construct measures of performance for higher education institutions, and that it wishes there to be a uniform system of validation of university courses. On academic tenure, the green paper says that the academic freedom of those who lack this privilege "is not visibly under threat". There is to be an inquiry into the role of UGC.

One of the recurrent themes of the green paper is the right of free speech within universities, and the government promises a reconsideration of the degree to which students' unions should be financed from public funds. Meanwhile, it asks that universities and polytechnics should do what they can to prevent students from suppressing unpopular views.

\title{
Agreement on marketing
}

\section{Washington}

HOFFMANN-LaRoche Inc. and ScheringPlough corporation have reached a truce in their battle over marketing rights for human leukocyte (alpha) interferon (see Nature 21 March, p.207). Under the terms of agreements reached last week, ScheringPlough will pay royalties to Roche if Schering-Plough's product is sold in the US market, while in Europe each will be free to sell its own product without infringing the other's patent rights. Terms for Japan are expected to be similar to those covering the United States.

Schering-Plough's interferon (trademarked Intron) is produced under licence from Biogen NV of Cambridge, Massachusetts and Geneva, Switzerland. Biogen holds a European product patent for alpha interferon produced by recombinant techniques and expects to receive a similar patent in the United States. Roche, however, holds a very broad US patent that covers all highly pure human leukocyte interferons. and the new agreements ๑) 1985 Nature Publishing Group recognize that Schering-Plough's product falls within the terms of the Roche patent.

The agreements mean that recombinant interferons will be commercially available while the patent claims are sorted out. Roche has challenged Biogen's European product patent and that challenge will be pursued despite the agreement that both can market their products; the outcome would be important if either company decided voluntarily to withdraw from the market, for example. In the United States, where both Intron and Roche's "RoferonA" alpha interferon are in clinical trials, the final outcome of the dispute will hang on the scope of the expected Biogen patent for recombinant alpha interferon. The agreements refer only to a specific type of alpha interferon, however; if other variants prove to have valuable properties, there could be more battles to come. In addition, both beta and gamma interferons are in clinical trials and marketing rights for them are likely to be keenly contested.

Tim Beardslev 